\title{
SOCIAL SECURITY PRI VATIZATION: WHAT IT CAN AND CANNOT ACCOMPLISH
}

\author{
by \\ Randal I P. Mariger \\ Board of Governors of the Federal Reserve \\ April 1997 \\ (Revised June 1997)
}

\begin{abstract}
This paper assesses the effect of social security privatization on the government budget, economic efficiency, national saving, and the distribution of resources across generations. It is shown that the benefits of privatization most often touted by privatization advocates can be achieved by simply altering taxes and social security pensions, and leaving the basic structure of social security unchanged. In the conclusion, two simple arguments are given for why privatization might be a good idea nonetheless.
\end{abstract}

The analysis and conclusions set forth in this paper are those of the author and do not indicate concurrence by other members of the research staffs, by the Board of Governors, or by the Federal Reserve Banks. 
Social security privatization is now receiving much attention in policy circles. Proposed privatization plans range from modest changes in the mix of assets held by the social Security Trust Fund, to the phased-in replacement of all social security benefits and taxes with mandatory Individual Retirement Accounts (IRAs). Most often, these plans are touted as means of closing the currently projected long-term social security funding gap while assuring all generations equitable treatment and adequate retirement income.

Privatization plans promise substantial benefits and Iittle or no prior sacrifice, suggesting that a "free I unch" is possible. Simple reasoning might seem to verify this conclusion. If the current social security system is phased out, and mandatory I RAs are phased i $n$, wouldn't national saving increase as pensions become fully funded? If pensions are fully funded, wouldn't the viability of fiscal policy be freed of its dependence on demographics, and wouldn't the marginal tax rate on Iabor income be reduced? If mandatory I RAs earn higher returns than the implicit returns individuals currently earn on social security taxes paid, couldn't the cost of securing currently promised retirement incomes be reduced?

Many economists, skeptical of free I unches, are naturally suspicious of these arguments. Indeed, claims made by many privatization advocates seem to conflict with three general economic principles. First, social security's projected funding shortfall simply reflects the fact that current law promises more net transfers than can be delivered; unless some source of economic inefficiency is lessened or eliminated, some individuals must accept smaller net transfers. Second, if the social 
security system has reduced national wealth (national saving), it is because it has transferred wealth from current workers and their descendants to earlier generations (Kotlikoff, 1979); such a decline in national wealth can be ameliorated only if wealth is somehow transferred from old generations to young generations. And third, absent an increase in national saving, directing more saving into corporate equities can only reshuffle claims to a fixed amount of capital income; increased equity investment by itself would do nothing to make more resources available to finance retirement consumption.

Can these general economic principles be squared with the arguments favoring privatization? If not, then where do the proprivatization arguments go wrong? It is to these questions that this paper is directed. I begin with an analysis of full privatization--the substitution of mandatory I RAs for all social security benefits and taxes-. in the context of a simple twoperiod model with complete certainty. Then key features of the real world are layered onto the model, and the conclusions are modified accordingly.

In the context of the simple two-period certainty model, my conclusions are:

; To the extent that privatization plans do not implicitly change taxes or retirement benefits, they merely transform unfunded government pension liabilities (i mplicit government debt) into explicit government debt. Hence, privatization increases pension funding only by as much as it decreases funding of the rest of government. Privatization per se does nothing to increase national saving, to lower marginal tax rates, or to reduce the uncertainty of future fiscal policy. 
; Several privatization plans claim to increase the efficiency of resource allocation, and to close the social security funding gap. However these plans i mplicitly call for higher taxes and lower pension incomes than are projected under current law. Explicit changes in taxes and benefits in the context of the current social security system would achieve the same ends.

; The burden that unfunded public pension liabilities and explicit government debt place on future generations, measured as a share of aggregate wages, is smaller the more rapidly aggregate wages grow. Privatization, to the extent that it substitutes explicit government debt for unfunded pension liabilities, does nothing to make the burden of future taxes less dependent on aggregate wage growt h.

When allowing for uncertainty and many pre-retirement periods, none of these conclusions is substantially changed. In this case, I find that:

; Full privatization would lead to retirement incomes with very different risk properties than those promi sed by the current social security system. However, it remains true that privatization per se would not help close the expected social security funding gap.

; To the extent that some individuals currently would I ike to borrow for the purpose of investing in equities but cannot, full privatizaton would unleash a pent-up demand for corporate equities. Absent a change in national saving, this shift in asset demands would lead to a reshuffling of claims to capital income, but would not increase resources available to finance retirement consumption.

; Any shift in asset demands would put upward pressure on the government borrowing rate, necessitating an increase in taxes. 
; The effect of a shift in asset demands on national saving would depend critically on how taxes necessary to finance higher net interest payments are distributed across generations. If older generations pay less of these taxes than they effectively receive in the form of higher government net interest payments, national saving would probably decline. Otherwise, national saving would probably be little changed.

; If the mandatory nature of mandatory I RAs forces some saving that would not otherwise occur, then privatization would have an additional effect on national saving. specifically, forced saving likely would be smaller under privatization than under the current social security syst em.

; Privatization would probably induce smaller tax-induced distortions in the timing of labor effort over the life cycle than would a comparable public social security system. A viable public system with a benefit formula like that currently in place effectively levies a pure labor income tax (one whose incentive effects are not off set by associated pension benefits) that varies substantially with age. Pure taxes under privatization would necessarily raise the same present value of revenue as those levied under the comparable public social security system, but they al most certainly would not be age-dependent.

The final part of the paper analyzes the effect of investing the Social Security Trust Fund in equities. For this case of partial privatization, I find that:

; The allocation of risk across individuals might be affected, but absent a change in national saving, aggregate risk and aggregate income would be unchanged. Also, the government's expected long-run fiscal balance might be improved, but individuals would be subjected to increased risk associated with uncertain changes in future taxes and government expenditures necessitated by the uncertain performance of trust fund investments. Individuals would not necessarily be better off 
shouldering this additional risk than they would be if taxes were instead increased, or government expenditures reduced, to achieve the same expected Iong-run fiscal bal ance.

; The change in national saving would depend on how taxes and government expenditures change in response to the returns on trust fund investments. For example, if taxes change frequently to off set unexpected changes in the value of the trust fund, then government equity investments would have little effect on the the distribution of resources across generations and national saving would be little affected. Alternatively, if taxes change infrequently and with a long lag, then the government's equity investments would transfer resources to old generations from younger generations. In this latter case, national saving would likely decline.

; The government borrowing rate might rise, necessitating higher taxes to finance higher net interest payments. As in the case of mandatory IRAs, these changes would have an additional effect on national saving that depends on the distribution of the tax increase across generations.

The remainder of the paper is organized as follows.

Section l analyzes privatization in the context of a simple twoperiod model with no uncertainty. Sections II, III, and IV then generalize the analysis to the case of uncertain rates of return and many pre-retirement periods. Trust fund investments are then analyzed in section V. Finally, section VI concludes that the si mple arguments put in favor of privatization are flawed, but that there are two very simple reasons why privatization might be a good idea nonetheless.

\section{FULL PRI VATIZATI ON WI TH NO UNCERTAI NTY}

To fix ideas, consider a simple model where each individual is certain to live two periods, a working period and a 
retirement period, and where all assets pay a certain real rate of return $r$. (The nominal return on government debt is assumed to be indexed for inflation.) Each young person of generation g (young at time $g$ ) pays social security taxes of SST $=\tau W_{g}$, where $\tau$ is the payroll tax rate and $W_{g}$ is labor income. Letting g be the implicit rate of return received on social security taxes for generation g, social security benefits received by each member of generation $g$ when retired are $S S B_{g}=\left(1+\eta_{g}\right) \tau W_{g}$.

As shown in table 1, this social security system can be interpreted in terms of mandatory implicit government bond purchases and net transfers. Specifically, divide generation g's social security taxes into forced implicit government bond purchases,

$B I_{g}=\left(1+\eta_{g}\right) \underset{g}{ } /(1+r)$, and a net transfer of

(1) $\quad T R_{g}=\left(\eta_{g}-r\right) \underset{g}{W} /(1+r)$.

Then the implicit bond would yield retirement income $(1+r) B{ }_{g}=$ $(1+\eta g) \tau W_{g}$, which is precisely the social security benefit amount, SSB . Note that only if $\eta_{g}$ exceeds $r$ is it possible that members of generation g are made better off by the social security system. $^{1}$ In this case, social security effectively subsidizes work effort. If $\eta_{g}$ is less than $r$, on the other hand, then social security imposes a tax on work effort.

To determine the the set of feasible transfers that a viable social security system can convey, it is necessary to

-- $\bar{A}^{-}$Tiquidity constrained individual might be made worse off by the social security system even if $\eta$ exceeds $r$. 
determine the time path of government debt as a function of these transfers. Supposing that the social security system begins with a tax levy at time 0 and benefits commencing at time 1 , explicit government debt at the beginning of time t attributable to the social security system is

$$
\left.D_{t}=(1+r)^{t} \sum_{g=0}^{t-1}\left(S S B_{g-1} N_{g-1}-S S T_{g} N_{g}\right)(1+r)^{-g}\right], \quad(t=1,2, \ldots)
$$

where $\mathrm{N}_{g}$ is the number of generation $g$ members. This is conveniently rewritten as:

$$
\begin{aligned}
& D_{t}=(1+r)^{t}\left[\sum_{g=0}^{t-1} N_{g}\left(S S B_{g} /(1+r)-S S T_{g}\right)(1+r)^{-g}\right. \\
&\left.\quad S S B_{-1} N_{-1}-S S B_{t-1} N_{t-1}(1+r)^{-t}\right] .
\end{aligned}
$$

Noting that $S S B_{-1}=0$ and $\left.S S B_{i+1} /(1+r)\right)$ - SST $T_{i}$ is the net transfer TR, that the social security system conveys to each member of generation i (see (1)), explicit government debt at time $t$ can be written:

$$
D_{t}=(1+r)^{t}\left[\sum_{g=0}^{t-1} N_{g} T R_{g}(1+r)^{-g}\right]-S S B_{t-1} N_{t-1}(t=1,2, \ldots) .
$$

At time $t$, the social security system owes retirees $S S B_{t-1} N_{t-1}$; hence, (2) implies that true government liabilities of the social security system at the beginning of time $t$ is

$$
D_{t}^{*}=(1+r)^{t} \sum_{g=0}^{t-1} N_{g} T R_{g}(1+r)^{-g}, \quad(t=1,2, \ldots)
$$


In order for this social security system to be viable, it is necessary that true government li abilities never exceed the present value of current and future wages. If this is true at any time $t$, then it must also be true at time $t-1$. Hence, the viability condition requires that:

$$
\lim _{\operatorname{tiB}}\left[D^{*}-\sum_{g=t}^{B} g^{N} g^{W}(1+r)^{-(g-t)}\right]<0 .
$$

Assuming that aggregate wages grow at rate less than $r$, I i $m(t \varsigma B) \sum_{g=t}^{B} \quad g_{g}^{N} W(1+r)^{(g-t)} \quad$ is finite and the viability condition requires that I i $m(t \varsigma B)\left[(1+r)^{-t} \stackrel{*}{D}\right]<0$, or:

$$
\sum_{g=0}^{B} N_{g} T R_{g}(1+r)^{-g} Z \underset{g=0}{\sum} \underset{g}{N}(\underset{g}{\eta}-r) \underset{g}{\tau W}(1+r)^{(g+1)}<0 .
$$

That is, the present value of the net transfers to all generations is no greater than zero. Any gain that a viable social security system conveys to one generation, therefore, must be at the expense of other generations. ${ }^{2}$

A social security system is pre-funded only if the system's viability does not require any net transfers from future generations. In the context of this model, the social security system is al ways pre-funded only if $\eta=r, i=0,1, \ldots$ I $n$ this case, there are no intergenerational transfers $\left(T R_{g}=\left(\eta_{g}-r\right) \tau \operatorname{W}_{g} /(1+r)=0, g=0,1, \ldots\right)$ and the social security

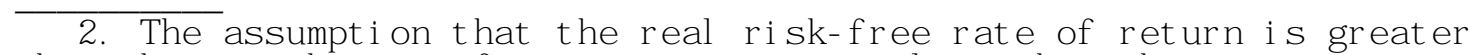
than the growth rate of aggregate wages implies that the economy is dynamically efficient. In the alternative case, a collective choice to decumulate capital can make all generations better off (Samuelson, $1958)$. 
system reduces to forced implicit government bond purchases. ${ }^{3}$

Typically, however, social security systems pay much higher benefits to early generations of retirees than would be warranted by market rates of return and taxes paid. In this case, $\eta_{\text {- }} r$ is positive for early generations and, for the viability condition (4) to hold, it must be true that $\eta_{\text {- }} r$ be negative for at least one later generation. In this case, the social security system effectively transfers wealth to early generations from later generations, and is not pre-funded.

It is readily apparent that ordinary taxes and debt issuance can achieve the same set of intergenerational transfers i mplied by a viable social security system. specifically, suppose that an incremental wage tax at rate- $\tau\left(n_{g}-r\right) /(1+r)$ is levied in period $g, g=0,1,2, \ldots$ Then the present value of each member of generation g's resources are changed by $\tau\left(n_{g}-r\right) W_{g} /(1+r)=T R_{g}$, as is true for the social security system. If borrowing is unrestricted at rate of interest $r$, then all individuals are indifferent between the social security system and this set of taxes. (With borrowing constraints, some generations might prefer the incremental taxes to the social security system. ${ }^{4}$ ) Moreover, this set of taxes implies incremental debt of

--- $\overline{3} \bar{y}-$ definition of pre-funding is often referred to as full funding. The full-funding label, however, can lead to confusion. Any viable social security system is, by definition, ultimately funded.

4. Relative to the social security system, the incremental taxes shift each individual's resources from the retirement period to the working period while maintaining the same present value of resources. Hence, relative to the social security system, the incremental taxes could only alleviate the effect of borrowing constraints. 


$$
\Delta q=(1+r)^{t} \quad \sum_{g=0}^{t-1} N_{g} T R_{g}(1+r)^{-i},(t=1,2, \ldots),
$$

which is precisely the true liabilities of the social security system $\left(D_{t}^{*}\right.$ from $\left.(3)\right)$.

It is well known that a purely pay-as-you-go social security system with constant tax rate $\tau$ pays each generation a rate of return on social security taxes equal to the growth rate of aggregate wages. This result is often read to mean that payas-you-go pensions are less burdensome in steady-state the more rapidly aggregate wages grow, which might seem to contradict the budget constraint (4) showing that the simple present value of transfers must be zero, no matter how rapidly wages grow. To show that there is no contradiction, it is useful to analyze a purely pay-as-you-go social security system with constant tax rate $\tau$ and constant aggregate wage growth $\rho$. In this case, generation 0 receives benefits of $\tau N_{1} W_{1}$ and pays no taxes. Its net I ifetime transfer is $N_{0} T R_{0}=\tau N_{1} W_{1} /(1+r)$. The net transfer received by later generations, which includes both a tax and a benefit component, is given by $N_{i} T R_{i}=\tau N_{i+1} W_{i+1} /(1+r)-\tau N_{i} W_{i}$ $=\tau N_{i} W_{i}(\rho-r) /(1+r), \quad(i=1,2, \ldots)$, which shows that the implicit rate of return, $\eta$, is indeed the growth of aggregate wages, $\rho$. It is easy to verify that the present value of all transfers is zero, no matter what the value of $\rho$ is. In effect, generation 0 creates a public debt $N_{0} T_{0}$ that future generations must pay off. The faster wages grow, the smaller is this burden as a portion of future wages. The absolute burden that generation 0 imposes on future generations, however, is independent of wage growth. 


\section{Privatizing a Viable Social Security System}

It has been established that a social security system can be interpreted as a system of mandatory implicit government bond purchases and net transfers. (See table 1.) This observation suggests an obvious means of privatizing a viable social security system. Suppose, for example, that the original social security system is such that generation 0 benefits at the expense of later generations $(\eta>r$ and $\eta<r$ for $g=1,2, \ldots \ldots)$ Then, for each generation $g, g=1,2, \ldots$, privatization could be accomplished by eli minating social security taxes and benefits, but requiring that the young buy (explicit) government bonds

$$
B_{g} Z(1+g) \underset{g}{\tau W} /(1+r) \text {, }
$$

and pay debt management taxes of

$$
\operatorname{TDM}_{g} Z-(\underset{g}{\eta}-r) \underset{g}{\tau} /(1+r) .
$$

As shown in table 1, cash flows of individuals would be precisely the same under this privatization scheme as would have been the case under the original social security system. The only difference is that explicit government debt would be substituted for i mplicit government debt (promises to pay retirement benefits) in individual portfolios. And, with individual portfolios essentially unchanged, rates of return would al so be unchanged. ${ }^{5}$

\footnotetext{
-- $\overline{5}^{--}$Tñ ${ }^{-}$order to design mandatory I RAs that yield that same retirement income as the initial social security system, each generation's implicit rate of return on social security taxes, $\eta$, must be known at the beginning of working life. Under the current social security system, real benefits depend on an lifetime average for "indexed" covered wages, where the index pertains to economy-wide average wages. Hence, with social security taxes proportional to covered wages, the implicit real rate of return earned on social security taxes depends on the time

(Footnote continues on next page)
} 
Table 2 verifies that privatization leads to a viable overall government fiscal policy provided the baseline time path for explicit government debt is feasible. At time 1, government debt is higher by the amount of tax revenue that is diverted into the mandatory I RAs of generation 1 members. The decline in social security benefits paid at time 2 frees up just enough government revenue to retire the incremental debt issued at time 1. At time 2, the pattern is repeated for generation 2. It is apparent, therefore, that government debt is increased at each point in time by the amount of taxes that are diverted into mandatory IRAs, and that fiscal policy under privatization is feasible provided that the baseline time path for government debt is feasible.

It is clear that privatization per se does not make the viability of fiscal policy less reliant on wage growth. The explicit debt created under privatization imposes an absolute dollar burden on future generations just as does the initial social security system; in both cases, this absolute burden is easier to shoulder the more rapid is wage growth. Likewise, privatization does not decrease so-called "political risk," as debt management taxes would be subject to as much political uncertainty as are social security taxes and benefits.

Also, privatization would have no effect on work incentives in this model. With public pensions, the net

(Footnote continued from previous page) profile for covered wages and economy-wide average wages, and is not known in advance. This feature of the real world is discussed in the next section. 
transfers defined in (1) are i mplicit taxes that drive a wedge between retirement contributions and retirement income. However, these implicit taxes are, under privatization, levied in the form of explicit debt management taxes.

\section{Non-neutral privatization deriving from non-neutral debt management $t$ axes}

The debt management taxes given in (7) are chosen so that the privatization scheme has no real consequences for any individual. More generally, the debt management taxes TDM' ${ }^{\prime}$ $(g=1,2, \ldots)$ need only satisfy the viability condition:

$$
\sum_{g=0}^{B} N_{g} T_{g} M_{g}^{\prime}(1+r)^{-g}=-N_{0} T R_{0^{\prime}}
$$

which is true if $\operatorname{TDM}_{g}^{\prime}=-(\underset{g}{\eta}-r) \underset{g}{W} /(1+r) Z-\underset{g}{R}$ as in (7). There are clearly many possibilities for the debt management taxes, each one of which yields a different distribution of resources across generations. But to achieve any particular distribution of resources across generations, it is not necessary to privatize the social security system. To see this, suppose the social security system is privatized as above except that the debt management taxes satisfying (8) are TDM' ${ }_{g}^{\prime}-T_{g}+\underset{g}{\delta}$ $(g=1,2, \ldots)$. Then the distribution of resources across generations yielded by this privatization scheme could be achieved by leaving the social security system unchanged and levying incremental taxes $\delta_{g}$ on each member of generation $g$, $g=1,2, \ldots$

Several studies claim to show that privatizing a viable social security system can improve "welfare." In many cases, 
these alleged improvements can be traced to debt management taxes that are brought forward in time relative to those that would be neutral with respect to resource allocation. Such a reallocation of the tax burden across generations induces increased national saving, l ower living standards for older generations, and i mproved l iving standards for younger generations. As has been demonstrated, such improvements in resource allocation, if indeed they are improvements, can be accomplished by simply bringing forward the time path of general taxes and leaving the social security system unchanged. ${ }^{6}$

\section{Non-neutral privatization deriving from non-neutral mandatory IRA contributions}

The mandatory I RA contributions given in (6) are chosen so that the privatization scheme leads to no change in real retirement incomes. Of course, a privatization plan would involve substantive change if mandatory I RA contributions differed from (6), in which case debt management taxes would necessarily differ from those given in (7). But it is clear that

\footnotetext{
--- $\overline{6}^{--} \bar{F} \bar{e} T$ astein (1995b) argues that privatization increases economic welfare in the context of a two-period model li ke that presented here. However, the allocation of resources achieved by his privatization scheme could be achieved by leaving the social security system unchanged and changing the time path for general taxes. That is, the welfare gains Feldstein identifies could be obtained simply by raising general taxes in the near term, thereby l owering government debt and raising capital accumulation, and lowering general taxes in later years.

Si mi larly, Kotlikoff (1995), si mulates a privatization model that is claimed to improve the efficiency of resource allocation by increasing the steady-state linkage between retirement contributions and ret irement income. This is accomplished by increasing taxes in the short term so that they can be reduced in the long term, and could be done just as effectively without altering the social security system. Kotlikoff, Smetters, Walli ser (1996) si mulate privatization efficiency gains that derive from levying debt management taxes in the form of consumption taxes. Again, these gains could be achieved by substituting consumption taxes for income taxes, while leaving the social security system unchanged.
} 
these substantive changes could be i mplemented by si mply adjusting social security benefits and taxes.

\section{Privatizing a Non-Viable Social Security System}

Any meaningful analysis of the advantages of privatization must define a viable public social security system as a standard for comparison. Unfortunately, in the case of the United States and other developed countries, this requires that the analyst make some arbitrary assumptions about how the social security system would, if it were to remain public, be modified to make it vi able.

It is, nevertheless, instructive to i magine privatizing a non-viable social security system. In particular, if such a system were privatized as in (6) and (7), the implied time path for explicit government debt would precisely equal the the infeasible time path for explicit and implicit government debt under the original public social security system. It follows that privatization by itself cannot turn an infeasible public retirement plan into a feasible private plan without putting the rest of government out of balance.

of course, the privatization plan given in (6) and (7) could be altered by raising debt management taxes so that privatization yields a feasible fiscal policy. Suppose, for example, that net transfers under the original social security system are such that:

$$
\sum_{g=1}^{B} N_{g}\left(T R_{g}+\delta\right)(1+r)^{-i}=-N_{0} T R_{0}, \delta<0 .
$$


Then debt management taxes of $\operatorname{TDM}_{g}^{\prime}=-\left(T_{g}+\delta\right), i=1,2, \ldots$, yields a feasible fiscal policy under privatization. But this policy is indistinguishable from a policy of simply raising taxes (general or social insurance taxes) by $\delta$ on all young individuals starting at

time 1, and leaving the social security system public.

The intuition for these findings is clear in the context of the current social security system. Recent calculations made by the Social Security Administration strongly suggest that every age cohort born on or after 1937 will, on average, receive a negative net transfer from the social security system defined by current law. (Advisory Council on Social Security, 1997.) ${ }^{7}$

The system is infeasible because these negative net transfers are not sufficiently large to counterbalance in present value the positive net transfers received by earlier generations, generations that are, for the most part, either dead or retired. Privatizing social security does nothing to take back the positive net transfers made to early generations, and hence does not help later generations to pay off the implicit debt that these early generations incurred. ${ }^{8}$

-- $\overline{7}$. $\bar{T} \bar{e} \bar{s}$ e calculations are for the social security system as defined by current law, except that it is assumed that the payroll tax rate will be revised each year after 2028 to that the projected Social Security Trust Fund balance remains zero in each subsequent year of the projection period. For the most part, the assumed payroll tax rate increase will affect individuals born in the early 1960's or later. These age cohorts al most certainly would receive negative net transfers from the social security system even if the payroll tax rate is not altered, and it was assumed that any funding shortfall is financed from some unspecified source.

8. Feldstein (1995a) argues that not privatizing Social Security violates the principle that "when you discover you are in a hole, the first thing to do is to stop digging. "This argument would be valid if

(Footnote continues on next page) 


\section{Intragenerational Transfers}

Thus far, it has been assumed that the public social security system offers all individuals of a given generation the same rate of return on social security taxes. In actuality, public social security systems redistribute income across members of the same generation. Some of these transfers can be interpreted as insurance. For example, low-income individuals earn a higher rate of return on social security taxes than highincome individuals (Steuerle, 1994). These intragenerational transfers, however, have no i mplications for the funding status of the overall social security system. To determine the funding status of the overall social security system, it is sufficient to know the average rate of return paid to each birth cohort. Hence, incorporating intragenerational transfers into the model would not change any substantive conclusions.

\footnotetext{
(Footnote continued from previous page) new entrants to the labor force recelve positive net transfers from the social security system, and if privatizaton invoked non-neutral debt management taxes that effectively elimi nated these positive net transfers. (However, the same result could be obtained by simply adjusting social security benefits and taxes.) But, as is documented in the text, new entrants to the labor force receive negative net transfers from the social security system.

Feldstein's view may be influenced by the observation that unfunded social security liabilities are growing over time, and the assumption that this growth would be stopped if privatization were to occur. To the contrary, the change in social security liabilities has two components: interest on al ready accrued liabilities, and newly-accrued li abilities. Newly-accrued li abilities are now negative each year. (Current workers, and all future age cohorts, receive negative net transfers under the current system.) Interest on al ready-accrued li abilities accumulates regardless of whether social security is, or is not, privatized.
} 


\section{FULL PRIVATIZATION UNDER UNCERTAINTY}

The analysis of section I assumes complete certainty. In this case, the implicit real rate of return earned on social security taxes and on government debt are known at the beginning of working life, and it is therefore possible to design mandatory I RAs that yield the precise same retirement income as does the initial social security system. In addition, with all assets paying a certain real return $r$, the increase in explicit government debt attributable to privatizing a viable public social security system would necessarily be incorporated into the I RA accounts of individuals forced to purchase I RAs, and the rate of return would not change.

This section considers the implications of introducing uncertainty into the analysis. I begin with the case where mandatory I RAs must be invested in indexed government debt. I then investigate the effect of allowing individuals the option of investing mandatory I RAs in risky assets.

\section{Mandat ory I RAs I nvested OnI y i n I ndexed Government Debt} Under the current social security system, real benefits depend on a lifetime average for "indexed" covered wages, where the index pertains to economy-wide average wages. Hence, with social security taxes proportional to covered wages, the implicit real rate of return earned on social security taxes depends on the lifetime time profile for covered wages and time profile for economy-wide average wages, and is not known in advance.

Likewise, with indexed government securities available only for I i mited maturities, assets do not exist that guarantee a real return on pre-retirement saving. 
Because of these uncertainties, the portion of social security taxes that would be diverted into mandatory I RAs under my prototypical privatization plan (see (6) and (7)) would be selected so as to yield the same expected retirement income as the baseline social security system, assuming that mandatory I RAs are invested 100 percent in indexed government debt. ${ }^{9}$ In this case, the section I results would carry over, but would be applicable only to expected values. In particular, privatization per se would not change the expected time profile for total government debt (implicit and explicit).

In this general case, or course, the stochastic properties of retirement income would be different under privatization than under the original social security system. From the perspective of individuals, it is not clear which probability distribution for retirement income and retirement "contributions" would be preferable.

\section{Risky I nvestment Options}

To understand the partial effect of risky investment options on the allocation of resources under privatization, we begin from a feasible privatization baseline that assumes that mandatory I RAs must be invested in indexed government debt. In this privatization baseline, we have established that the allocation of resources is not materially different than under the comparable viable public system.

$-\bar{g}^{--} T \bar{t}^{-}$is assumed that the increase in explicit government debt attributable to privatization would be issued as indexed debt, as such debt would probably best substitute for current social security benefit promises. However, my qualitative arguments would not be affected if the increase in explicit government debt was not indexed. 
Under the initial viable social security baseline, individual portfolios include four assets: promised social security benefits (i mplicit indexed government debt), explicit indexed government debt, non-indexed government debt, and real capital. ${ }^{10}$ privatization substitutes explicit indexed government debt for implicit indexed government debt. If individuals willingly incorporate the new increased supply of explicit indexed government debt into their mandatory IRAs, then nothing in effect changes.

However, some individuals undoubtedly currently hold more indexed government debt (implicit and explicit), and less real capital, than they would I ike given prevailing rates of return. Such individuals would like to take out indexed loans for the purpose of investing in real capital, but cannot. In this case, privatizing social security would shift asset demands toward real capital and away from indexed government debt, causing the return on government debt to rise so that individuals would willing hold the same amount of government debt (explicit and implicit), and the same amount of real capital, as is held under the initial social security system. The higher return on government debt, of course, requires higher taxes if government non-interest expenditures remain unchanged from baseline.

In this scenario, two interesting questions arise: How is national saving affected? and Does the changed allocation of risk appreciably increase individual welfare?

-- $\overline{1} \overline{0}^{--} \bar{T} \bar{e}$ returns to real capital are paid to owners of debt and equity. For our purposes, we can consolidate the private sector and assume there is no corporate debt. 


\section{National Saving}

Only if national saving were to rise would it be possible that privatization would increase resources available to finance retirement consumption. ${ }^{11}$ On this score, national saving would be influenced through four principal channels.

Higher Risk-Free Return and Higher Taxes

An increase in the risk-free return to saving has two opposing effects on saving: the rewards to saving are increased ( substitution effect), and less saving is necessary to achieve any given level of future purchasing power (wealth effect). Which saving effect is stronger depends on individual preferences and the timing of labor income. The current empirical evidence is not very robust, but suggests that saving is relatively unresponsive to the rate of return. ${ }^{12}$

Higher net interest payments necessitate higher taxes. The timing of these taxes is crucial, as it would determine how the combination of increased taxes and higher government net interest payments affect the intergenerational distribution of

- - $\overline{1} \overline{1}-\bar{A} T \bar{s} \overline{0}$, privatization might induce corporations to accommodate an overall increased tolerance for risk by investing in more risky investment projects. In this case, the mean and variance of the return on real capital would increase. This effect is probably of second order i mportance.

12. Among the largest credible estimates of the compensated savings el asticity (substitution effect) is 0.4. (Michael Boskin, "Taxation, Saving, and the Rate of Interest, "Journal of Political Economy, January 1978.) Unfortunately, this result may not be very robust because of the I i mitations of the available data. The aggregate U.S. ti me-series data Boskin analyzes includes few significant changes in the tax law, and individuals respond to changes in the tax law with unknown lag times. cross-section data on individual saving is no more helpful. At any point in time, the after-tax return varies across individuals only because income varies; it is difficult to reliably separate the effect of income from the effect of the after-tax return on individual savings decisions. 
resources. Suppose, for example, that each generation pays the taxes necessary to finance the increase in government net interest payments that it receives. That is, taxes are raised on generation 1 at time 1 to cover the increase in net interest payments received by generation 1 at time 2, and all future generations are taxed in a similar manner. (As in section I, privatization is assumed to start with generation 1.) Then, consumption while young would decrease for all generations. In effect, each generation's increase in taxes would neutralize the wealth effect of the increase in the rate of return, leaving only the positive substitution effect.

Alternatively, suppose, as is likely, that taxes are increased to cover net interest expenses on a pay-as-you-go basis. Relative to the pre-funding case, generation 1 pays fewer taxes and later generations pay more taxes. That is, funding incremental net interest payments on a pay-as-you-go basis rather than on a "pay-your-own-way" basis transfers resources to generation 1 from later generations. Such intergenerational wealth transfers decrease national saving (Kotlikoff, 1979). Hence, the total effect on national saving in this pay-as-you-go scenario can be divided into two parts: the increase in saving that would occur if incremental net interest payments were prefunded, and the decrease in saving that occurs because generation 1 receives a wealth transfer from later generations. Which of these two effects is I arger is theoretically ambiguous. It would appear, however, that saving would fall unless the the substitution effect of a change in the rate of return is substantial. 
Direct Effect of Loosened Portfolio Constraints

For an individual whose portfolio is constrained under the original social security system, loosening the constraint through privatization would increase the perceived returns to saving even if the risk-free return were unchanged. This would affect have the same two opposing effects on saving as does the higher riskfree return. ${ }^{13}$ In addition, loosened portfolio constraints would decrease the incentive to save in order to fund additional equity investment. On bal ance, it is likely that loosened portfolio constraints would lead to less national saving.

Amount of Forced Saving

It has been shown that privatization is neutral with respect to national saving if mandatory I RA contributions must be i nvested in government debt, and if these contributions are just I arge enough to maintain the baseline level of retirement income. All privatization proposals, however, call for mandatory IRA contributions that yield baseline retirement income assuming higher than risk-free rates of return. It follows that forced saving, if positive under the original social security system, might decline under privatization.

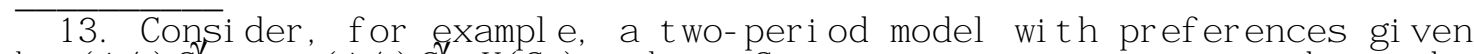
by $(1 / \gamma) C_{1}+(1 / \gamma) C_{2} U\left(C_{2}\right)$, where $C_{i}$ is consumption in period $i$ and $(1 /(1-\gamma))$ is the elasticity of intertemporal substitution. If there is one asset paying certain return $r$ and one risky asset paying uncertain return r, then the portion of the agent's portfolio invested in the risky asset, $\alpha$ is chosen so as to maximize $k^{*} Z E\{(1 / \gamma)[1+r+\alpha(r-r) \gamma\}$, where $E$ is the mathematical expectation. The saving decision depends on rates of return entirely through the value of k*. (See Hakansson (1970).) Hence, if liquidity constraints cause $\alpha$ to be less than optimal, the value of k* declines just as if $r$ was made smaller. Hence, a suboptimal portfolio allocation would have a qualitatively similar effect on saving as would a decline in the risk-free rate of return. 
Equity Prices and the Return on Real Capital

Thus far, it has been implicitly assumed that the real

return distribution on real capital is unchanged by

privatization, and that all changes to relative real rates of

return occurs through the increase in the real risk-free return.

In this case, the price of corporate equities is unchanged by privatization.

This assumption is in fact valid if the savings influences al ready discussed net to little or no change in the overall incentive to save, as our analysis suggests. To see this, consider the alternative case where the price of corporate equities rises and the real return distribution for real capital shifts downward. Then the overall incentive to save would be smaller than if equity prices remained unchanged, suggesting that privatization would decrease the overall incentive to save. But, if the overall incentive to save were to fall, then Tobin's q (market value of equities divided by replacement cost) would not rise above its long-run equilibrium level, a contradiction.

Su mma ry

To sum up, it is unlikely that national saving would be much changed by privatization. If higher government net interest payments were pre-funded with i mmediate tax increases, national saving would probably increase a small amount. Otherwise, national saving might fall. ${ }^{14}$

-- $\overline{1} \overline{4}^{-}{ }^{-} \bar{p} T$ an to investigate these issues further in the context of a general equilibrium si mulation model. 


\section{Wel fare Consequences}

By loosening portfolio constraints, privatization might lead to a more efficient allocation of risk-bearing. In particular, privatization would allow young individuals with low levels of privately managed wealth, and who are unable to obtain private investment loans, to effectively increase their holdings of equity and decrease their holding of implicit indexed government debt (promises to pay future indexed social security benefits). These individuals, in effect, would receive indexed government loans financing equity investments. Individuals whose portfolios are currently unconstrained, of course, would respond to the higher government borrowing rate by holding more government debt and less equity. Absent a change in national saving, the total amount of government debt (i mplicit and explicit) and the total amount of real capital would be unchanged, but the allocation of risk would change.

Quantifying the potential welfare gains arising from a changed allocation of risk is beyond the scope of this paper. I conjecture, however, that reasonably prudent individuals would want to accumulate a portfolio of safe assets while working that is sufficient to ensure a living standard in retirement at least as great as is currently promised by social security. Such individuals would invest mandatory I RAs that substitute for public pensions in safe assets. ${ }^{15}$ Moreover, to the extent that some individuals are not reasonably prudent, society arguably has a legitimate interest in constraining their investment choices so

-- $\overline{1} \overline{5}^{--} \bar{T} \bar{T} \bar{s}$ choice would be evident in the composition of individuals' overall privately managed portfolios, and not necessarily in the mandatory I RAs themsel ves. 
that they are less likely to prey on the altruism of more prudent individuals.

Also, any welfare gain resulting from a changed allocation of risk is offset by welfare loss attributable to higher taxes financing net interest payments. In effect, privatization substitutes one tax for another. The initial social security system imposes an implicit tax on individuals who are forced to hold more (implicit) government debt in their portfolios than they would like given the prevailing return on government debt, and this implicit tax induces an inefficient allocation of risk. Privatization substitutes an explicit tax for this implicit tax. Which tax is more distortionary is an open question.

\section{III, ISSUES ARISING FROM MULTIPLE PERIODS}

In the context of the two-period model of section I, it was shown that any change in marginal tax rates on labor income caused by privatization could be accomplished by simply modifying general taxes and leaving social security unchanged. In a multiperiod setting, however, a public social security system and its privatized counterpart would have very different implications for the timing of labor effort over the life cycle. To illustrate this point, consider a very simple example where a worker earns average covered wages in every year of his 35 year working life. Supposing this individual began work in 1995, an additional dollar of labor earnings at age A (also year A) would increase real OASI taxes by $\tau$ (the OASI tax rate, currently 10.55 percentl and would increase real monthly social security benefits at age 67 (the normal retirement age in 2030) by. 32*IND/35, where IND $A$ is a real wage index factor, and all amounts are 
expressed in year A dollars. The real wage index factor is a complex function of age because wages earned prior to age 60 are indexed to age 60, and later wages are unindexed. Hence, the index factor is:

$$
\begin{aligned}
I N D_{A} & =\left(R W_{60} / R W_{A}\right)\left(P_{60} / P_{67}\right), \quad(A=33,34, \ldots, 60), \\
& =P_{A} / P_{67},(A=61,62, .66),
\end{aligned}
$$

where RW is an index of economy-wide real wages, and $P$ is a general price index. In present value terms, the individual gives up $\tau$ and receives $V_{A} *\left[.32 * 1 N_{A} / 35\right]$, where $V_{A}$ is the value at age $A$ of receiving a inflation-adjusted dollar each month beginning at age 67 assuming a normal real rate of return. ${ }^{16}$ Hence, the total "tax" $\tau$ on the last dollar of labor income at age A decomposes into an investment of $V_{A}^{*}\left[.32 * 1 N_{A} / 35\right]$ and a transfer of $V_{A} *\left[.32 * 1 N D_{A} / 35\right]-\tau$. This transfer arises from an additional dollar of income at age $A$, and hence is a marginal transfer rate. How the marginal transfer rate varies with age depends on two offsetting factors prior to age 60: the value of a dollar annuity beginning at age $67\left(V_{A}\right)$ increases with age, whereas the cumulative growth of average real wages between year A and year $60\left(R_{60} / R W_{A}\right)$ declines with age. If the real discount rate exceeds the growth in real average wages, as one would expect, then the marginal transfer rate would increase with age up to age 60. After age 60, the marginal transfer rate rises

\footnotetext{
-- $\overline{1} \overline{6}$. $-\bar{T} \bar{T} \bar{e}^{-}$social security benefit formula includes discontinuities. The assumption that the individual earns average real wages ensures that the social security pension increase $\$ 0.32$ for each additional dollar of average indexed covered earnings.
} 
with the general price level. ${ }^{17}$

Figure 1 gives an illustrative profile for the marginal transfer rate assuming a 3 percent real discount rate, a 1 percent annual growth of real economy-wi de average wages, and a 3 percent rate of general price inflation. The marginal transfer rate varies from-5.7 percent (a tax) in work year 1 to 1.3 percent (a subsidy) in work year 35. Lifetime transfers as a share of wages are-1.1 percent. The simple lifetime average of the marginal transfer rate is - 3.5 percent. Hence, for this individual, the social security system assesses a lifetime tax equal to roughly 1.1 percent of wages, but imposes an marginal tax rate on labor income that averages 3.5 percent. This divergence between the average tax rate and marginal tax rate is attributable to social security's redistributive role; social security is a less-good deal the more a worker earns.

Marginal tax rates under a privatized social security system would very much depend on the details. For a prototypical model like the one in section l, debt management taxes are the key. These taxes can be levied in any manner consistent with the revenue requirement given in (8). If these taxes do not depend on age, as do the taxes implicit in the current social security system, privatization would probably reduce tax-induced distortions in the timing of labor effort over the life cycle.

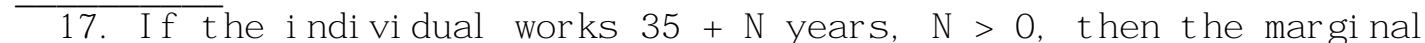
transfer rate is equal to mi nus the OASI tax rate for the $N$ years with l owest indexed covered earnings. This is because only the highest 35 years of indexed covered earnings matter for the computation of social security benefits. 


\section{THE ILLUSORY BENEFITS OF PRI VATIZATI ON}

Several privatization plans have been proposed recently. Perhaps the most prominent and ambitious plan, the so-called "Schieber plan," was put forward by a coalition of members of the 1994-96 Advisory Council on Social Security. It would phase in a two-tier retirement system where retirement income is made up of an indexed demogrant financed by payroll taxes, and the proceeds on mandatory I RA contributions made by individuals while working. The new system would apply fully to individuals age 25 and younger in 1998; older individuals would receive retirement benefits that are a combination of benefits earned under the current system and benefits earned under the new system. Under the plan, government-paid retirement and disability benefits would be financed with a basic 7.44 percent payroll tax plus a special 1.52 percent supplementary tax levied for 72 years (1999. 2070). Mandatory IRA contributions would equal 5 percent of covered payroll, so that basic payroll taxes plus mandatory IRA contributions would equal total payroll taxes under current law (12.44 percent of covered payroll). The plan would initially lead to increased explicit federal debt, but the incremental debt would be fully paid down by 2070.

The advantages of this plan are touted by its creators largely in terms of a "money's worth ratio" (MWR), " the ratio of the present value of expected retirement income to the present value of expected payroll taxes and mandatory I RA contributions (Advisory Council on Social Security, 1997). It is estimated that the plan would substantially increase the average MWR for

nearly all age cohorts relative to baseline public system. For this estimation, the baseline public system (PL-PAYGO) is the 
current system modified to remain viable by increasing payroll taxes in each year beginning in 2029 to ensure that the Social Security Trust Fund remains nonnegative.

These MWR calculations suggest that all generations can be made better off by privatization, which would seem to contradict my finding that the current social security system merely transfers wealth across generations, and that privatization can only modify these wealth transfers in such a way as to leave the present value of transfers unchanged. However, there is no contradiction because the MWR is not meaningful as calculated. The MWR calculations assume that about half of mandatory IRA contributions would be invested in corporate equities earning a 7 percent real return, but the real discount rate used to discount portfolio returns is the 2.3 percent return assumed on long-term U.S. Government securities. It is clearly inappropriate to discount a risky income stream by a risk-free return. In any event, the fact that mandatory I RAs are invested in equities can increase aggregate retirement income only if national saving is somehow increased. Otherwise, equities held in mandatory IRA accounts are simply shifted from other private accounts, and total private-sector portfolio returns would be unchanged. To objectively analyze the schieber plan, or any other privatization plan, it is essential to separate the plan into two parts: mandatory IRAs, and publicly-paid retirement benefits and the taxes that finance them. Mandatory I RAs entail no transfers, and hence should be ignored when considering questions of equity or fairness. Absent mandatory IRAs, the schieber plan amounts to a reduction of payroll taxes and a reduction of retirement benefits. It is this part of the schieber plan (schieber ex 
(RAs) for which measures of intragenerational and

intergenerational fairness should be estimated and compared with the same measures under PL-PAYGO. Unfortunately, no such esti mates have been made. ${ }^{18}$ It is necessarily true, however, that such estimates would show that not all age cohorts are made better off by privatization. As was shown in section l, the current social security system has transferred resources from current workers and their descendants to earlier generations. This transfer was financed with i mplicit debt; privatization can only redistribute the burden of this debt across later generations-.it cannot lessen the total burden.

In 2070, the Schieber plan calls for smaller unfunded pension liabilities, and the same level of explicit federal debt, than in the the PL-PAYGO baseline. Hence, total government debt (explicit and implicit) in 2070 is lower under the schieber plan than under the PL-PAYGO baseline. It necessarily follows that the schieber plan transfers resources from the old to the young relative the PL-PAYGO baseline. Such transfers, which derive entirely from the non-IRA part of the Schieber plan, would increase national saving. ${ }^{19}$ But this increase in national saving does not derive from mandatory IRAs; it derives entirely from reforms to the public social security system--the decrease

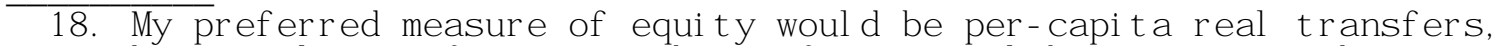
or perhaps real transfers as a share of pre-tax labor income. The money's worth ratio measurers gain or sacrifice as a portion of the present value of taxes paid, and can be misleading if the taxes paid as a share of wages varies across generations.

19. Of course, the increase in national saving would have no relation to the size of mandatory IRAs, or the returns earned in mandatory IRAs. Hence, the fact that national saving might rise under the schieber plan does not justify the methodology for estimating MWRs.
} 
in taxes that is more than offset by the decrease in publiclyfinanced retirement benefits.

In addition, mandatory I RAs might "force" some saving.

Under the schieber plan, this would occur only if some individuals would like to save less than 5 percent of their covered wages in some years.

\section{PRI VATIZING TRUST FUND I NVESTMENTS}

To date, the social security system has taken in more taxes than it has paid in benefits. The cumulative difference between taxes and benefits as of the end of 1996, the value of government securities held in the social security Trust fund at that time, was about 1-1/2 times as large as current annual social security benefits paid. This trust fund accumulated because the baby boom generation is funding part of its own retirement. This phenomenon is evident in the simple two-period model; some taxes are paid at time 0 but no benefits are paid until time 1 , so that the "trust fund" has a positive balance $(1+r) N_{0} \tau W_{0}$ at the beginning of period 1 .

If the current social security system were fully privatized i mmediately, then a large portion of current social security taxes would be diverted to IRAs. Benefits accrued under the original social security system would then be paid out of greatly diminished social security taxes, the trust fund, and general revenues. Because the trust fund would be depleted in a a relatively short time, how those funds are invested would be of little consequence.

Some analysts, however, have advocated a partial privatization scheme where social security remains public but the 
trust fund is invested in private-sector assets. The economic effects of this policy, compared with some feasible alternative policy, depends critically on how social security taxes and benefits change in response to the trust fund's rate-of-return performance. Suppose, for example, that social security benefits are fixed and that taxes are frequently modified to reflect the trust fund investment performance. Then trust fund equity investments would have mi nimal real effects, as the sharing of aggregate risk would be I argely unchanged. Alternatively, if taxes respond with a long lag to the trust fund investment performance, then trust fund equity investments would change the distribution of risk bearing across generations. In this latter case, trust fund equity investments would benefit older generations via a higher return on risk-free assets, and could make later generations either better or worse off ex ante.

In formally establishing these findings, use is made of the fact that the economic effects of government equity i nvestments does not depend on whether these investments are inside of or outside of the social security accounts. Investing $\$ X$ of the trust fund in equities, while leaving taxes and expenditures unchanged, requires that the government issue an addition $\$ X$ of debt to the public. In effect, the government would be borrowing for the purpose of investing in equities. The economic effects of this transaction would not depend on whether or not a social security system is in place. Hence, to analyze the economic effects of investing all or part of the trust fund in equities, it is sufficient to analyze the economic effects of the government borrowing for the purpose of investing in equities without any regard for the particulars of social security. 
The analysis below considers three cases. The first case assumes taxes that respond every year in accordance with the return earned on the trust fund, and that investors can borrow at the risk-free market return. The second case allows for borrowing constraints. Finally, the third case assumes a long I ag between trust fund investment performance and changes to taxes that ensure I ong-run budget balance. In all cases, government expenditures are assumed to be independent of trust fund performance. A more general analysis, which would allow both government expenditures (social security benefits) and taxes to respond to trust fund returns, would not change any substantive conclusions.

\section{Annually Changing Taxes, No Borrowing Constraints}

A simple example illustrates the core issues. ${ }^{20}$

Starting from a feasible baseline where the government owns no equities, suppose the government at time 0 issues $\$ X$ of additional debt and buys $\$ X$ of equities, and changes taxes each year so as to maintain the baseline time path for government net financial wealth (equity mi nus debt). Consider the effect of this change on an individual who pays the share $\alpha$ of federal taxes. In year 1, this individual's taxes change by his share, $\alpha$, of the government's year-1 portfolio loss (perhaps negative):

$$
\Delta T_{1}=-\left(r_{K 1}-r_{b 1}\right) \alpha X
$$

where $r_{b 1}$ is the certain nominal return on government bonds and $r_{k 1}$ is the uncertain return on equities. However, suppose this

\footnotetext{
- $\overline{2} \overline{0}^{-} \bar{M} \bar{y}-\bar{n}$ alytical approach is si milar to Smetters (1997), but was arrived at independently.
} 
person had increased his debt holdings by $\alpha X$ and decreased his equity holdings by $\alpha X$ in response to the government's equity investment. Then his capital income in year 1 changes by:

$$
\Delta Y_{1}=\left(r_{K 1}-r_{b 1}\right) \alpha X
$$

which exactly offsets the change in taxes. The same logic applied to future years implies that the change in taxes plus the change in capital income would be identically zero in all years for an individual who consciously hedges the government's equity investment as in this example.

But would investors hedge the change in the government's portfolio? For someone who owns risk-free assets in the baseline or is able to borrow at the risk-free return rbl' and who is rational and well-informed, the answer is yes. In the baseline, such an individual chooses a mix of debt and equity that best suits his or her tastes. The government's equity investment, if not hedged, would upset this mix; effectively, it would increase the individual's equity holdings and decrease the individual's debt holdings. The individual has the means to neutralize this change, and would rationally do so.

This conclusion might seem to conflict with estimates showing that investing all or part of the Social security Trust Fund in equities would help close the expected social security funding gap. These estimates suggest a free I unch; the government can put its finances in order by selling its own debt to willing buyers and using the proceeds to buy equities from willing sellers. Wouldn't this policy leave individuals better off than would an alternative policy of raising taxes or reducing 
government expenditures? If so, then it would appear that government equity investments would have real effects.

This paradox--that government equity investments effective change nothing, but appear to improve the government's fiscal bal ance without adversely affecting individuals--is resolved once account is taken of risk. Supposing government equity investments are sufficient to ensure long-run fiscal balance in an expected value sense, they would nevertheless introduce an additional element of risk into taxes. To achieve actual longrun fiscal balance, the present value of taxes must be adjusted to reflect the difference bet ween the actual I ong-run performance of the governments' portfolio and its expected performance. This additional tax risk makes individuals worse off just as would an increase in the variance of portfolio returns. Thus, there should be no presumption that government equity investments are a I ess burdensome means of achieving long-run fiscal balance than would be si mple tax increases or expenditure reductions.

\section{Annually Changing Taxes, Some Borrowing Constraints}

Some individuals undoubtedly hold less equity than accords with preferences for risk and return, and would rationally choose not to hedge government equity i nvestments. This might be true of young individuals whose privately managed financial wealth is small, and who are unable to borrow for the purpose of making equity investments. Individuals in this category would wel come the opportunity to effectively own more equity and less debt (more loans) through their relationship with government.

To the extent that I iquidity constraints are prevalent, privatization would unleash some pent-up demand for equities and 
cause the government borrowing rate to rise. The consequences for national saving and individual welfare exactly parallels the case, discussed in section II, where the introduction of mandatory I RAs increases the demand for equities.

\section{Lagged Tax Response}

A key assumption of the analysis thus far is that individuals who are subjected to future random tax changes because of government equity investments at time $t$ are able to make investment choices at time t that neutralize the randomness of future taxes. This requires, of course, that affected individuals be al ive at time t.

The alternative case is easily analyzed in the context of the two-period model introduced in section l, where the preretirement period and the retirement period each represent many years. Starting from a feasible fiscal policy, suppose the government at time 0 and every period thereafter issues a oneperiod $\$ X$ bond and invests the proceeds in private equities. Suppose further that tax changes make up the loss on the government's equity investments with a one-period lag. Then the change in taxes levied on the young, relative to the initial baseline, is

$$
\Delta T_{i}=\left(r_{b, i-1}-r_{K, i-1}\right) X,(i=1,2, \ldots, .
$$

where, for period t, $r_{b t}$ is the certain real return on government debt and $r_{k t}$ is the uncertain real return on private equity. In effect, the young of generation $i, i=1,2, \ldots$, are forced to own $\$ X$ of vintage i- 1 capital and - $\$ X$ of vintage i- 1 government debt. 
Generation 0's taxes are unchanged, but they are nevertheless made better off by the government's equity investment. When young, this generation must be induced to hold $\$ X$ more government debt and $\$ X$ I ess equity than in the baseline, which requires that the return on government bonds, 'bo' rise. Since net saving is positive in the pre-retirement years, this rise in the rate of return improves generation o's well-being. Two factors influence the change in generation l's wellbeing: the random component of taxes, ( $\left.r_{b 0}-r_{k 0}\right) x$, and the change, relative to baseline, in the government bond rate, $\Delta r_{b l}$. If the equity return in period 0 equals the bond return l $r_{b 0}=$ r $k 0$ ), so that the incremental tax on generation 1 is zero, then generation 1 is in the exact same position as was generation 0 , and hence is made better off because $\Delta r_{b 1}>0$. It follows that there is some positive number c such that generation 1 is better off provided that $r_{k 0}>r_{b 0}-c$.

It is demonstrated in the appendix that the mathematical expectation at time 0 of generation $1^{\prime} s$ lifetime utility is increased by the government's equity investment policy, provided the scale of the investment $(X)$ and initial debt issuance is sufficiently close to zero. Hence, there is some possibility that government equity investments would be pareto improving. Intuitively, there are two reasons for this result. First, by holding some vintage 0 capital in addition to vintage 1 capital, generation 1 is better able to diversify its risks. Second, and perhaps more important, the uncertainty associated with investment in vintage 0 capital is resolved prior to the time generation 1 makes any economic choices, whereas uncertainty associated with investment in vintage 1 capital is not resolved 
until after generation 1 chooses first period consumption. Hence, generation 1 is more flexible in its response to the realization for rko than it is to the realization of r $k 1$ ' and hence is better able to shoulder the first risk than the second.

\section{SUMMARY AND CONCLUSION}

Some of the claims made by privatization proponents are indeed too good to be true. Relabeling social security taxes mandatory I RA contributions, or shifting asset demands so as to reshuffle claims to given amounts of capital income, do nothing to increase resources available to finance retirement consumption. Granted, privatization plans have been proposed that are apparently feasible, which can't be said of the current social security system. However, all of these plans implicitly raise taxes and decrease retirement benefits in a manner that would put the current social security system in balance.

Current misperceptions regarding privatization tend to derive from a basic mi sunderstanding of the nature of a pay-asyou-go social security system. Such a system is often likened to an investment that yields a return equal to the growth rate of aggregate wages. This conceptualization is mi sleading because it is only true for a mature system; when a pay-as-you-go social security system is first started, it conveys a transfer to retired individuals that boosts consumption and reduces capital intensity and capital income. Hence, the current social security system is best conceptualized as a wealth transfer from current workers and their descendants to earlier generations. Much of this wealth transfer has already been consumed. What hasn't been 
consumed is held by currently retired individuals, individuals that would not be affected by privatization. ${ }^{21}$ Thus, the damage has been done. The essential issue now is how to spread the burden of the implicit debt al ready incurred by individuals that are either dead or retired across l ater generations. However it is decided to spread this burden, it can be done within the context of the current social security system.

So as to address the false claims of some privatization proponents, I have focused on those aspects of privatization that amount to empty shell games. I have not emphasized those aspects of privatization that constitute real change. Most i mportantly, the risk characteristics of pensions would necessarily be very different under privatization than under a system like that currently in place. Also, all proposed privatization schemes call for a revised system of government transfers between members of the same age cohort. In evaluating privatization plans, these are i mportant considerations.

While the arguments most often put forward in favor of full privatization are flawed, there are nevertheless two potentially good reasons to privatize. First, individuals might be made to feel more personally responsible for their own economic well-being, which could have a pervasive influence on economic choices generally. And second, individuals might become better informed voters. This latter possibility is suggested by the confusion surrounding the privatization debate itself. It is

-- $\overline{1} \overline{1}-\bar{T} \bar{i} \bar{s}$ statement concerns weal th transfers to the various age cohorts. Of course, some current workers can expect to receive positive net transfers from the social security system. But transfers within an age cohort have little or no implication for capital accumulation, or the funding status of the social security system. 
probably true that individuals understand explicit government debt better than the implicit government debt that the current social security system engenders. If so, then privatization, by transforming the current unfunded liabilities of the social security system into explicit government debt, and by removing the current social security surplus from the government accounts, might make individual voters better aware of the current state of fiscal policy.

There is little to recommend investing the Social security Trust Fund in equities. This policy would have little effect on national saving, and hence would merely lead to a reshuffling of claims to a fixed amount of capital income. While there would be some potential for improving the allocation of risk across generations, and of relieving the effects of borrowing constraints, there is no reason to believe that these benefits would be I arge. 


\section{REFERENCES}

Report of the 1994-96 Advisory Council on Social Security, Findings and Recommendations (vol. 1), and Reports of Technical Panel on Assumptions and Methods (vol. 2).

Congressional Budget office (1994), "I mplications of Revising Social Security's I nvestment policies," CBO Papers, Sept ember.

Feldstein, Martin, and Andrew Samwick (1996), "The Transition Path in Privatizing Social Security, NBER working paper 5761 , september.

Feldstein, Martin (1995a), "The Missing Piece in Policy Analysis: Social Security Reform," American Economic Review, Vol. 86, No. 2, May.

Feldstein, Martin (1995b), "Would Privatizing Social Security Raise Economic Welfare?" NBER Working Paper 5281. Sept ember.

Hakansson, Nils H. (1970), "Optimal Consumption and I nvestment Strategies Under Risk for a $\mathrm{Cl}$ ass of Utility Functions," Econometrica, Vol. 38, pp. 587-607.

Kotlikoff, Laurence J. (1979), "Social Security and Equilibrium Capital Intensity," Quarterly Journal of Economics, Vol. 93, pp. $233-255$.

Kotlikoff, Laurence J. (1995), "Privatization of Social Security: How it Works and Why it Matters," NBER working paper 5330 , october.

Kotlikoff, Laurence J., Kent Smetters, and Jan Walliser (1996), "Privatizing Social Security-. A Si mulation Study," Mi meo, November.

Mitchell, Olivia S., and Stephen P. Zeldes (1996), "Social Security Privatization: A structure For Analysis," NBER working paper 5512, March. 
Smetters, Kent (1997), "Investing the Social Security Trust Fund into Equity: Unmasking the Large Hidden Actuarial Tax Liability on Future Generations," mi meo, April.

Samuelson, Paul (1958), "An Exact Consumption Loan Model of Interest With or Wi thout the Social Contrivance of Money," Journal of Political Economy, Vol. 66, No. 4, December.

Steuerle, C. Eugene and Jon. M. Bakija (1994), Retooling Social Security for the 21 st Century, Washington D.C., The Urban Institute. 


\section{APPENDI X}

\section{PARETO I MPROVI NG GOVERNMENT EQUITY I NVESTMENTS}

In the text, it was asserted that government equity investment can improve the welfare of all generations if the scale of the investment, and the baseline level of government debt, are sufficiently small. This result is derived here in the context of a two-period model. The strategy is to show that a infinitesimally small level of government equity investment is pareto improving when the baseline level of government debt is zero. In addition, the case of positive baseline government debt is briefly discussed.

\section{Government Equity Investment When Baseline Government Debt is} Zero

Consider a two-period model where one person is born each

year. The young individual at time $t$ earns $Y$, pays $t a x e s T_{t}$, consumes $C_{y t}$, and invests in government bonds $B_{t}$ paying certain return $r_{b t}$ and real privately-owned capital $k_{t}$ paying uncertain return ${ }^{k}$. Assuming no taxes are levied on

elderly individuals, the elderly individual at time $t+1$ consumes:

$$
C_{e, t+1}=\left(Y_{t}-C_{y t}-T_{t}\right)\left(1+r_{K t}\right)+B_{t}\left(r_{b t}-r_{K t}\right),
$$

When young, the individual chooses $C_{y t}$ and $B_{t}$ land implicitly real

capital $\left.K_{t}\right)$ to maximize expected utility $V=E_{t} U\left(C_{y t}, C_{e}, t+1\right)$, where $E_{t}$ denotes the mathematical expectation conditional on information available at time $t$. The supply of bonds is 
exogenous, and may be zero. Wi thout loss of generality, the government is assumed to provide no public goods.

In the baseline, the government issues no debt and real capital is the only investment option. In the alternative case analyzed here, the government issues $\beta$ Y units of debt at the beginning of time 0 , where $\beta$ is between zero and one, and uses the proceeds to buy buy $\beta$ r units of real capital. At time 1, taxes on young individuals are set to exactly cover the government's investment losses $T_{1}=\left(r_{b 0}-r_{k 0}\right) \beta Y$, and the supply of government bonds returns to zer 0 .

Given $r_{b 0}$ and the probability distribution for ' $\mathrm{KO}^{\prime}$ generation 0 chooses $C_{y 0}$ and $B_{0}$ to maximize $E_{0} U\left(C_{y 0}, C_{e 1}\right)$, where:

$$
C_{e 1}=\left(Y-C_{y 0}\right)\left(1+r_{b 0}\right)+B_{0}\left(r_{b 0}-r_{K O}\right)
$$

This maximization defines demand functions $C_{*}^{*} c_{\text {yo }}^{*}=C_{y 0}^{*}\left(r_{b 0}\right)$ and $B_{0}^{*}=B_{0}^{*}\left(r_{b 0}\right)$. The equilibrium bond yield $r_{b 0}^{*}$ is such that:

$$
B_{0}^{*}\left(r_{b 0}^{*}\right)=Y \beta
$$

An equilibrium bond yield exists provided that the supply of government bonds ( $\beta Y$ ) is sufficiently small. It can be verified that $r_{b 0}^{*}<E_{0}\left(r_{k 0}\right)$.

Generation 0 is necessarily made better off by the government's debt-financed real capital investments. From the individual's perspective, investing entirely in real capital is al ways an option, so the existence of government bonds expands the opportunity set of agents. At the margin, the return on government bonds is such that agents are indifferent between holding government debt and holding real capital. On 
inframarginal government debt, however, agents receive a higher return than is necessary to compensate for smaller holdings of real capital.

Generation l's problem is similar to that of generation 0 , except that it faces taxes equal to the government's net loss on it's capital investment at time $0, T_{1}=\left(r_{b 0}-r_{k 0}\right) \beta Y$, and the supply of government bonds is zero. Hence, generation 1 chooses $C_{y 1}$ to maximize $E_{1} U\left(C_{y 1}, C_{e 2}\right)$, where:

$$
c_{e 2}=\left(Y-\beta Y\left(r_{b_{0}}-r_{K_{0}}\right)-c_{y_{1}}\right)\left(1+r_{K 1}\right) \text {. }
$$

The first order condition for the optimum is:

$$
E_{1}\left[U_{1}-U_{2}\left(1+r_{K 1}\right)\right]=0 \text {, }
$$

where $U_{i}$ is the partial of the utility function $U$ with respect to its $i^{t h}$ argument. This optimality condition determines $c_{y}^{*}$ as a function of ( $\left.r_{b 0}-r_{k 0}\right)$.

How the government's debt/investment policy affects the well-being of generation 1 depends on the realization of $r_{b o}$ 'ko' As of time 0 , however, it is possible to show that generation 1 is made better off in an expected value sense for $\beta$ sufficiently small. To see this, consider the effect on generation 1 of increasing $\beta$ by a small positive amount $H \beta$. Then the change in generation l's expected utility is:

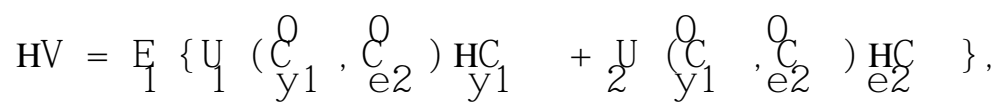

where $\mathrm{HC}_{\mathrm{e} 2}$ is given by

$$
\mathrm{HC}_{\mathrm{e} 2}=-\left(1+r_{K_{1}}\right)\left[\left(r_{b_{0}}-r_{K_{0}}\right) Y_{H \beta}-{ }_{y 1}^{H C}-\beta_{0} Y_{H}\right]
$$

Utilizing (A1) and (A3), (A2) can be expressed as:

$$
\left.\mathrm{HV}=4 \mathrm{Y}\left(\mathrm{H} \beta \mathrm{K}^{r} \mathrm{O}-\mathrm{b}^{r} \mathrm{o}\right) \cdot \beta_{0} \mathrm{H}^{r}\right) .
$$


The change in expected utility depends on ( $\left.\mathrm{r}_{0}-\mathrm{r}_{0}\right)$ directly and indirectly through $U_{1}$. As of time 0 , the expected change in expected utility due to a small change in $\beta$ is:

$$
E_{0}(H V)=Y H \beta_{0} E\left\{k_{k}^{r} \quad-b_{0}^{r} \quad 1 U\right\}+{ }_{1}^{U} Y_{B} \beta H^{r} .
$$

Because $U_{1}$ and $r_{K O}$ - $r_{b 0}$ are negatively correlated, $E_{0}(\mathrm{HV})$ may be positive or negative in the general case. Evaluated at $\beta$ equal to zero, however, $U_{1}$ is independent of $\left(\mathrm{r}_{\mathrm{kO}}-\mathrm{r}_{\mathrm{bO}}\right)$ and

$$
\left.E_{0}(H V)=Y H \beta_{1} U_{0} E\left\{k_{K^{r}}^{r}-b^{r}{ }_{0}\right)\right\}>0
$$

for $\beta$ initially zero. Hence, for sufficiently small $\beta$, the government's debt/i nvestment strategy would make generation 1 better off ex ante. Hence there is scope for a pareto i mprovement. The intuition for this result is given in the text.

The same logic implies that it would also be desirable from the perspective of generation 1 and generation 2 for the government to continue engaging in some debt-financed purchases of real capital. As we've seen with regard to generation 0 , generation l's payoff from such an arrangement would increase monotonically with the amount of debt issued. The expected payoff to generation 2 would depend on the relationship bet ween debt issuance and the return it must pay generation 1 on government bonds, rbl. This relationship, in turn, depends on generation 1's wealth; the better the government's real capital investment at time 0 paid off (the larger is r $\mathrm{KO}^{-} \mathrm{r}_{\mathrm{b}}$ ), the larger is generation 1's wealth and the lower is rbl for any given amount of debt held by generation 1 . Hence, the "best" $\beta$ from generation 2's perspective would be positively related to $r_{K O}-r_{b O}$ 


\section{The Case with Positive Government Debt in the Baseline}

For the case where the government issues debt in the baseline, it is not generally possible to conclude that a small amount of government equity investment would be pareto improving. The reason is that government debt by itself lowers steady-state welfare, and issuing more debt for the purpose of making equity investments raises the market return on debt and worsens the steady-state welfare loss attributable to the baseline level of debt. The market rate of return on debt matters for steady-state welfare, or course, because it helps determine the size of the transfer received by young individuals at the time the incremental debt is first issued. 


\section{TABLE 1}

\section{TWO I NTERPRETATI ONS OF SOCIAL SECURITY \\ NET PAYMENTS FOR GENERATI ON t}

\section{Conventional Interpretation}

Taxes when young (SST $\left.t_{t}\right) \quad \tau W_{t}$

Benefits when retired $\left(S S B_{t+1}\right) \quad(1+\eta) \tau W$

\section{Alternative Interpretation}

When young:
Forced I mplicit Bond Purchase
$(1+p) \tau \mid f /(1+r)$
Net Transfer $\left(T R_{t}\right)$
$(\eta-r) \tau W /(1+r)$

When retired:
I mplicit Bond Proceeds
$(1+\eta) \tau W$ 


\section{TABLE 2}

\section{EFFECT OF NEUTRAL PRI VATIZATI ON ON THE GOVERNMENT BUDGET}

\begin{tabular}{|c|c|c|c|}
\hline & & $\Delta$ Noninterest & \\
\hline Ti me & $\Delta$ Taxes & Expenditures & $\underline{\Delta E x p l i c i t ~ D e b t}$ \\
\hline 0 & 0 & 0 & 0 \\
\hline 1 & $-(1+\eta) \tau_{1}^{N} W_{1} /(1+r)$ & 0 & $\left(1++_{1} \eta \mathfrak{f}_{1}^{N}{ }_{1} W /(1+r)\right.$ \\
\hline 2 & $\left.-\left(1+\eta_{2}\right) \tau\right) \quad W /(1+r)$ & $-(1+q) \tau N_{1} W_{1}$ & $(1+\eta 2) \tau_{2}^{N} 2^{W} /(1+r)$ \\
\hline 3 & $-\left(1+\eta_{3}\right) \tau \tau_{3} W_{3}^{W} /(1+r)$ & $-(1+2) \tau N_{2} W_{2}$ & $(1+\ldots) \tau_{3} N 3^{N} /(1+r)$ \\
\hline ; & ; & ; & \\
\hline ; & ; & ; & \\
\hline t & $-(1+\eta) \tau_{t}^{N} W^{\prime} /(1+r)$ & $-\left(1+\eta_{-1}\right) \tau N_{t-1} W_{t-1}$ & $(1+\eta) \tau_{t} \mathbb{N}{ }_{t} W /(1+r$ \\
\hline
\end{tabular}

